\title{
Environmental Ethics and the Ideology of Meat Eating
}

\author{
Michael Allen Fox \\ Queen's University
}

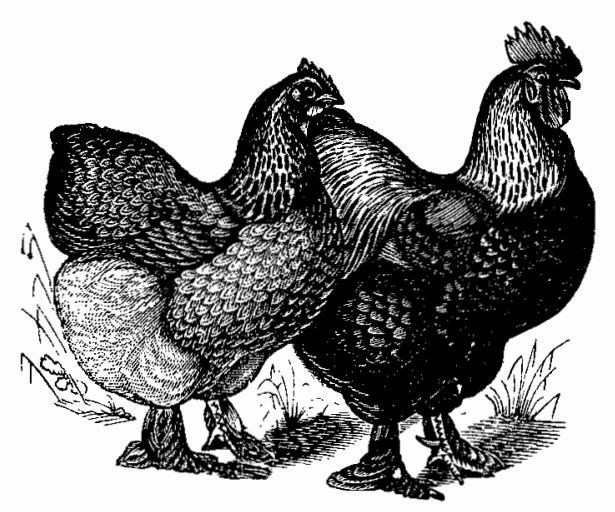

\section{A Dietary Approach to Evaluating Environmental Ethics}

This essay begins at the intersection of two controversies that are of considerable importance to contemporary discussions about the relationship between our species and the rest of nature. One concerns the question of whether a compelling case can be made for vegetarianism on moral grounds. The other has to do with the debate between proponents of animal rights and ethical holists over which kind of theory provides a more adequate foundation for a new environmental ethic. My remarks have their origin in some personal observations as well. Over the past decade and a half I have been a participant in numerous conferences, seminars and workshops on themes having to do with animal rights or animal liberation; I have also been involved in many centering on problems in environmental ethics. These have all been positive experiences for me in one way or another, and have, I believe, expanded the horizons of everyone present. Yet I could not avoid noticing that when I am at an animal rights or animal liberation conference it is a foregone conclusion, an essential premise, that all food presented to delegates

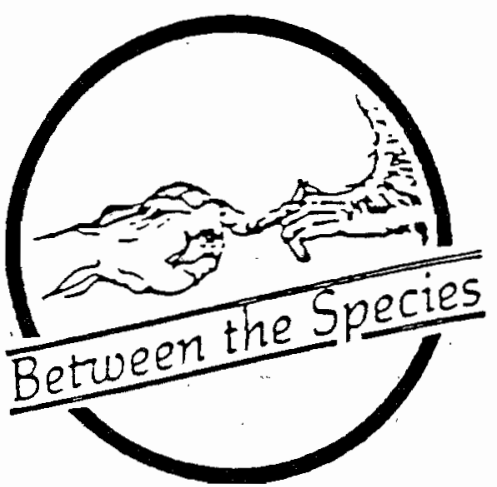

shall be vegetarian, even vegan. In contrast, conferences occupied with topics in environmental ethics commonly display no such commitment; and as a matter of fact, I find myself at these gatherings surrounded by persons discoursing earnestly on the subtleties of biocentrism, the land ethic, value theory, deep ecology, Gaianism, and so forth who are simultaneously tucking lustily into steaks, chops, bacon, and even veal with no apparent qualms. At one recent conference on environmental ethics and sustainable development, of some fifty participants only two others besides myself had requested vegetarian meals. At another, a workshop on environmental ethics and higher education, I was the only one of thirty participants not eating meat.

In case it may be thought that too much weight is being placed here on one source of evidence, it should also be noted that of seventeen general anthologies of contemporary work in environmental ethics or environmental philosophy that have appeared since 1974 , only one contains an essay specifically devoted to agricultural issues. ${ }^{1}$ None contains an essay that treats the topic of meat as an environmental problem. The same omission is found in monographs in these fields. (Ecofeminists, however, do engage this issue ${ }^{2}$ and appear to be the only group of theorists for whom it is anything like a central concern. What this entails will be considered briefly in section 5.) What does it all mean? Before I attempt an answer let me say that I find

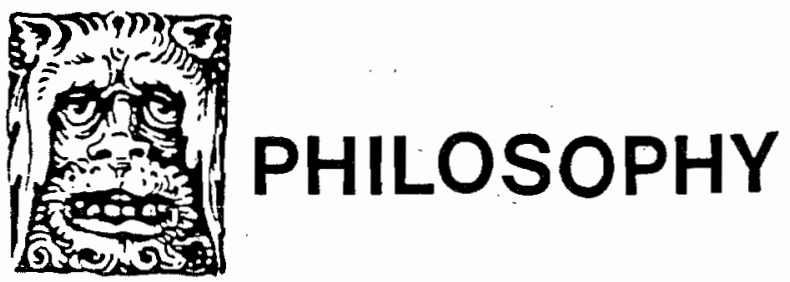


the situation just described to be highly problematic and anomalous. It took me a while to get a clear focus on this discrepancy - which I suggest is not just between two systems of thought (animal rights/animal liberation theory and environmental holism), but between a form of thought and actions that are incompatible with it. Environmental ethicists are very sincere and dedicated individuals, and a few are even political activists. Most are reasonably well informed and committed to seeking change in our dealings with the biosphere. But it would appear that many also fail to see any inconsistency between spearheading a search for a new ethic of the environment and continuing to eat meat. Could it be that this is only an appearance of inconsistency? After all, it seems obvious that animal rights advocates or animal liberationists would be acting in a radically inconsistent fashion if they ate meat; but is it so clear that environmental ethicists would likewise be? Many of them would say it is not, arguing that their concern is with the survival of species, the overall quality and carrying capacity of vital ecosystems, wilderness preservation, the aesthetic and other values embedded in the biosphere, and similar holistic objects of interest. They might add that humans, as naturally occurring components of ecosystems, should feel free to eat whatever they wish. From such a standpoint the fate of individual animals, or even of large numbers of animals purpose-bred for human consumption (which are certainly not members of endangered species), matters relatively little. However, I argue that this sort of objection is ethically myopic and no more than selfserving; it is an example of the kind of compartmentalized thinking that humans have practiced far too long and from which environmental ethicists had promised to deliver us. It is a kind of thinking that must be abandoned if human and other forms of life are to coexist and flourish on this planet.

\section{Seeing Things Whole: The Quest for an Ecological Ethic}

William Frankena once wrote that:

every ethics that is at all complete is or includes an ethics of the environment, since every such ethics, new or old, tells us, at least indirectly, what we may or may not, should or should not do about plants, lakes, minerals, etc.; and, therefore, the main question is not which are old and which new, but which is the most satisfactory (Frankena 1979: 4).

This seems a surprisingly liberal interpretation of the Western ethical tradition. One can of course refuse to regard an ethical theory as "at all complete" unless it includes some reference to the environment; but this would merely succeed in making Frankena's claim circular and vacuous. Or one could vindicate his position by observing that if a theory does not mention the environment at all, we receive "guidance" from this very fact in that none of our actions having a potentially deleterious impact on the environment could be proscribed by the theory, or the damage itself morally condemned. This would count as an "implication" all right; but then one might as well say that every ethical theory is concerned with the full range of our actions, of every conceivable kind, whether specified by it or not. This, however, seems to yield a reductio ad absurdum. While it may be acknowledged that whatever is not morally prohibited is therefore morally permissible, it would strike many as a travesty that an ethical theory which is completely permissive with respect to the natural world should, notwithstanding that fact, count as an environmental ethics. Indeed, one would also wonder what all the controversy in this field is about if it could be said that the ecological viewpoint is so deeply embedded in our tradition as Frankena might be held to suggest.

Aldo Leopold, on the other hand, reflecting on the same ethical tradition, wrote that the "single premise" of all ethics is "that the individual is a member of a community of interdependent parts" (Leopold 1970: 239). He suggests that "Ethics are possibly a kind of community instinct in-the-making" (Leopold 1970: 240).As the latter observation indicates, Leopold takes an evolutionary or process view of the history of ethics. That this is so can be illustrated by quoting him at greater length:

This extension of ethics, so far studied only by philosophers, is actually a process in ecological evolution. Its sequences may be described in ecological as well as in philosophical terms. An ethic, ecologically, is a limitation on freedom of action in the struggle for existence. An ethic, philosophically, is a differentiation of social from anti-social conduct. These are two definitions of one 
thing. The thing has its origin in the tendency of interdependent individuals or groups to evolve modes of cooperation. The ecologist calls these symbioses. Politics and economics are advanced symbioses in which the original free-for-all competition has been replaced, in part, by co-operative mechanisms with an ethical content (Leopold 1970: 238)

Leopold's statement assumes a contractarian view I should want to challenge: that humans are self-seeking social atoms, whose mutually repelling tendencies need to be suppressed and overridden by some institutionalized control mechanism. The error here, if it is one, lies in overlooking or downplaying humans' cooperative and caring instincts as well as the essentially social constitution of personhood. In spite of these reservations, however, Leopold's perspective on ethics not only appears plausible and suggestive, but also fruitful as a sort of heuristic principle for investigating the history of ethics. Moreover, it is arguably truer to what we observe of the changing preoccupations of normative ethical theory, particularly over the past two or three centuries. For much of this activity has been concerned with rethinking the principles of ethics in such a way that they can be extended and applied to previously disenfranchised and marginalized persons and other entities.

In what follows, therefore, I shall assume, for the sake of argument, that Frankena was wrong and Leopold was correct: in short, thoughtful reflection in the late twentieth century on human activity and its impact upon the planet, as well as on the remarkable properties and capacities of other life-forms, entails that a new ethics of the environment is both urgent and imperative; and that such an ethical paradigm shift is both theoretically and practically feasible. This assumption having been made, we can now focus on the issue of environmental ethics and vegetarianism.

Prior to considering why many environmental ethicists still eat meat, I had become convinced that there is an unbridgeable gulf between theories of environmental ethics and animal liberation and animal rights views. This was because the former tend to be holistic and communitarian and the latter individualistic and aggregative in their conception of what constitutes the good of a collectivity. Animal liberation and animal rights theories (and for that matter respect for life theories as well) tend to fix boundaries between those entities that deserve moral consideration and those that do not. Even though the division that results looks different from the old human/nonhuman dichotomy of traditional ethics, there is a tendency to cling to hierarchical thinking. Holistic theories of environmental ethics, by contrast, overleap certain boundaries and seek to define a more ecologically informed position. Whether these differences represent genuine incommensurabilities or, rather, conceptual rifts that can be healed by some rapprochement between views is of course a large issue on which much effort has been expended (Regan 1982; Taylor 1986; Stone 1987; Callicott 1989; Johnson 1991), and I shall not take it up here. What I do want to observe, however, is that on the basis of this characterization, one would expect environmental ethicists to be especially sensitive to connections between issues that pertain to our relationship with nature, particularly of course ethical issues, and to take a cultural (even cross-cultural) and global environmental perspective on such matters as lifestyle and diet. This I find they often fail to do, and the question is why. But before we seek an explanation of this lack of insight, let us first examine the grounds for connecting environmental concern with vegetarianism.

\section{Making Connections: The Case for Vegetarianism}

There are of course many grounds that might be adduced in support of choosing to be a vegetarian. However, four seem to stand out:

1. assuring good health for ourselves;

2. alleviating animal suffering and preventing unnecessary animal deaths;

3. helping avoid environmental damage and depletion; and

4. addressing the world hunger problem, which is closely related to the problem of social injustice.

With respect to good health unless one endorses a doctrine of duties to oneself $\mathrm{f}^{3}$ or has in mind one's obligations to others, one's own state of well being is a consideration of prudence, not of morality. In any event the statistical correlation between high meat consumption and increased probability of colon, breast and other cancers, heart disease and atherosclerosis-far and away the leading causes of death in North Americahas been well established by many independent researchers (Robbins 1987; Barnard 1990; Fiddes 
1991). There is no doubt that a vegetarian diet is better for one's health. And if one wishes to argue that maintaining good health is a moral obligation and not merely a matter of prudence-a duty to oneself or to others, such as one's family -then there are even more compelling reasons to be a vegetarian for health reasons.

The second argument concerns the reduction and/ or elimination of animal suffering and death, both of which are products in abundance of the agribusiness industry and in particular of modern intensive livestock rearing methods or "factory farming." This suffering and death has been widely documented by various observers and writers (Mason and Singer 1980; Singer 1990 ). For some suffering is the central or only issue; utilitarians typically regard animals as fully replaceable, and for them the special wrongfulness of factory farming consists in the brutal procedures characteristic of that activity: forced, life-long confinement in artificial and barren environments, forced impregnation, debeaking, separation of veal calves and piglets from their mothers in early infancy, crowded caging, social deprivation, suppression of grooming and other speciesspecific behaviors, and cruel transportation, holding and slaughtering methods. If the pain and suffering inherent in these practices could be eliminated, then for those whose sole preoccupation is with such things, no ethical issue would remain. Painless, instantaneous slaughter following a reasonably decent, if short, domesticated life would be an acceptable outcome. For others, who see animals as irreplaceable individuals or "subjects of a life" in Tom Regan's sense (Regan 1983: 243), this is unacceptable because such individuals are bearers of rights, preeminent among these being the right to life.

It is not my purpose here to try to settle this dispute but, rather, to indicate that the problem of vast amounts of suffering contingent upon current livestock rearing and marketing practices is a real one that we cannot ignore, no matter what our philosophical persuasion. Some may subscribe to the view that animal suffering and death in colossal quantities does not matter morally, or that if it does matter, its ethical import is offset or neutralized by the human enjoyment of animal products and the various forms of economic gain generated by satisfaction of human wants that are dependent upon using animals for food. However, human enjoyment in eating meat and economic gains accruing to the meat, egg and dairy industries could be realized in a vegetarian economy just as well. And because far less suffering would be generated, the overall utility of the latter system, one reasonably assumes, would be greater, and therefore the system itself would be morally preferable.

Now most people apparently do not care very much, if at all, about these issues. However, this lack of caring may point to a self-serving, or self-protective blind spot in people's moral consciousness. For as Bentham pointed out long ago, and many others since have reaffirmed, animal suffering should concern us because all forms of suffering should concern us-or at the very least suffering that is comparable in kind and degree to what we are familiar with at first hand. And a diet that depends on massive mechanized carnage should at least give us pause to consider what we are doing to satisfy our palates. As Carol J. Adams has argued, "Meat eating is the most oppressive and extensive institutionalized violence against animals" (Adams 1991: 70). So even if we don't subscribe to the very strong view that "Meat is murder," we should still be appalled at the magnitude of the death-dealing we acquiesce in by being meat eaters: in excess of five billion sentient beings are slaughtered annually in the United States alone (Singer 1990: 95). If figures like these leave one indifferent, it would appear that a certain moral numbness has set in, which ought in itself to signal the need for some serious self-reflection. It is difficult to avoid drawing the conclusion that we must each face up to the fact that our choices as consumers materially affect the amount of animal suffering and death. We either opt in or we opt out of the animal agony system. If we do not think too carefully or too critically about our diets, we can easily overlook the consequences they have; but this is also a choice, namely, a choice of omission. We are no less responsible for it than for any other choice. And if we are informed about the misery created by factory farming and related activities, yet still knowingly elect to eat meat, we are even more culpable.

An alternative way of understanding this form of neglect is that it springs from our culturally conditioned perception of our food and how as individuals we choose, more or less consciously, to affirm it in our daily lives. That is, each of us sees animal flesh in a market or present before us cooked upon a plate as either "meat" (or some "cut" thereof) or as body parts of a once living, now dead animal, perhaps even related to us as a natural kin. It is obvious that the former way of seeing tends to evoke thoughts and feelings of pleasure, comfort, hunger, nourishment, well-being, and the like, while the latter may be accompanied by thoughts and feelings of horror, disgust, displeasure, uneasiness, 
perhaps even guilt. The basis for either set of reactions is not "purely subjective": both are grounded in meaningful interactions with the world and shared attitudes toward it. The main point is simply that ethical responses here, as elsewhere, are contingent on how we (choose to) see the world and relevant items in it. If there is a significant sense in which we choose how we perceive animal flesh offered for food, or at any rate ought to become aware of how we perceive it and why, then it follows again that we are responsible for our actions that proceed from our way of seeing.

The third ground for vegetarianism mentioned earlier has to do with the environmental impact of meat production. The eco-destructive consequences of the meat industry's operations have been summarized concisely, with ample documentation from both governmental and non-governmental sources, by John Robbins in Diet for a New America (Robbins 1987). These include: toxic chemical residues in the food chain, pharmaceutical additives in feeds, polluting chemicals and animal wastes from feedlot runoff in waterways and underground aquifers, topsoil loss caused by patterns of relentless grazing, domestic and foreign deforestation and desertification owing to the clearing of land for grazing and for cultivating livestock feed, threatened habitats of wild species of plants and animals, intensive exploitation of water and energy supplies, and finally ozone depletion owing to the extensive use of fossil fuels and to significant production of methane gas by cattle. Even without citing supporting facts and figures, this litany of ecological woes surely ought to concern even the most undaunted environmental ethicist. That it apparently does not exercise many-at least as revealed by their writings and personal dietary habits-calls for explanation.

Fourth is the case for vegetarianism drawn from the world food crisis. Over twenty years ago in her book Diet for a Small Planet, Frances Moore Lappé described the wasteful feedlot process of rearing cattle for beef as "a protein factory in reverse" (sixteen units of protein input for each one of output [Lappé 1975: 11]; other estimates place the ratio as high as twenty to one, and the ratio of caloric input to caloric output for human consumption at ten to one [Fiddes 1991]). She also reported her "discovery that in 1968 the amount of humanly edible protein fed to American livestock and not returned for human consumption approached the whole world's protein deficit!" (Lappé 1975: 3). Lappé pointed out that the poor countries of the world are often net exporters of food to the more affluent countries (this, apparently, remains the case today); that ruminants could graze entirely on marginal rather than prime agricultural lands because they efficiently produce protein from cellulose; and that the North American food production system basically feeds animals, not people. The latter finding has received confirmation recently from Alan Durning, senior researcher at the Worldwatch Institute, who contends that nearly forty percent of the world's grain and seventy percent of American grain are fed to livestock (Durning 1991). Meanwhile Oxfam estimates that $\mathbf{1 4 . 6}$ million hectares of often choice land in developing nations is dedicated to producing animal feeds for European livestock (Gold 1991). Michael Redclift places the figure much higher, at 21.6 million hectares (Redclift 1987: 93). According to another report, "Worldwide over one-third of all grain is grown to feed livestock, whilst at least 500 million people are malnourished" (Fiddes 1991: 211). An estimated sixty gallons of water are needed to produce a pound of wheat, but a pound of meat requires 2500 gallons (Fiddes 1991: 215). These are scarcely rational uses of abundant but ever more precious planetary resources.

The average North American is overfed and overproteinized; this is too well known to be debatable any longer. According to David Pimentel, who has been studying the environmental impact of modern agriculture for more than a decade, per capita daily consumption of protein in the United States is 102 grams (70 of which is of animal origin), while the United Nations Food and Agricultural Organization's recommended level is 41 grams (Pimentel 1990). As Robbins points out, people in the developing world "are copying us. They associate meat eating with the economic status of the developed nations and strive to emulate it. The tiny minority who can afford meat in those countries eats it, even while many of their people go to bed hungry at night, and mothers watch their children starve" (Robbins 1987: 351). He estimates that "a given acreage can feed twenty times as many people eating a pure vegetarian [or vegan] diet-style as it could people eating the standard American diet-style." The same acreage would feed between six and seven lacto-ovo vegetarians (Robbins 1987: 352). Meanwhile, Lester Brown of the Overseas Development Council calculates that a mere ten percent reduction in American meat eating would free up enough grain to feed all of the sixty million humans who starve to death annually (Brown, cited in Robbins 1987: 352). Robbins concludes that "Hunger 
is really a social disease caused by the unjust, inefficient and wasteful control of food" (Robbins 1987: 353). Exploitation is clearly a principal feature of this "disease," as the poorest countries of the world find their traditional agricultural practices and diets increasingly undermined, their peoples increasingly undernourished, their lands deforested for grazing, their position in international markets undermined, and other negative effects of the international meat economy controlled by multinational corporations visited upon them (Redclift 1987; Gold 1991; Fiddes 1991).

Production, distribution and control of the market are the complex, dynamic elements that reinforce and perpetuate these forms of exploitation. Their scope goes beyond what we have space for here. Suffice it to say, however, that everyone has a clear choice between abetting the conditions which enable the "social disease" of world hunger to flourish and saying "no" by means of her or his own dietary commitments. Most environmental ethicists have not dissented in this mannerjust as they have failed to discuss the impact of the international meat economy on the environment-and again this calls for explanation.

The third and fourth grounds for vegetarianism illustrate, when considered together, just the sort of connection environmental thinkers should be making. For when unsustainable meat production takes its toll on the environment and consumes an inordinate share of the earth's resources, everyone is impoverished, especially those who are already short of food. These cumulative effects of the preferred North American diet are concisely summarized by Keith Akers at the conclusion of a very detailed discussion of what he labels "vegetarian ecology":

In the long run, we are all going to be vegetarians. Doubtless through further exploitation of the environment, we can prolong the period in our history in which we think it necessary to kill animals for food. But the ecological limitations of this procedure will soon make manifest to all that a vegetarian economy is both necessary and desirable.

Only a small minority of the world's citizens will ever be able to consume meat at current American levels: the resources to support a more intensive livestock agriculture simply don't exist. We will probably not feel the real effects of our present actions in the realm of agriculture for another twenty or thirty years. In the interim, things will merely become slightly less pleasant, year after year. To continue to maintain a meat economy can only make matters increasingly difficult for everyone, and can only adversely affect the goals of health for everyone and world peace (Akers 1983: 140).

If it is true that "Meat production is a major source of environmental damage" (Bloyd-Peshikin 1991: 67), why don't environmental ethicists oppose it in every way they can? Why don't they uniformly take a stand in favor of vegetarianism, not only by advocating it in their writings, teachings and presentations at conferences but also by adopting it as a personal dietary commitment? Why aren't they voting with their forks? The generous interpretation would be that they do not see the connections between environmentalism and vegetarianism and between meat eating and environmental destruction, or at any rate that they do not see them very clearly or appreciate their force. If, however, they do see the connections, these are not as a rule acknowledged or acted upon, which would appear to indicate a lack of caring and even a form of ethical negligence. To unravel what's going on here, we need a deeper explanation.

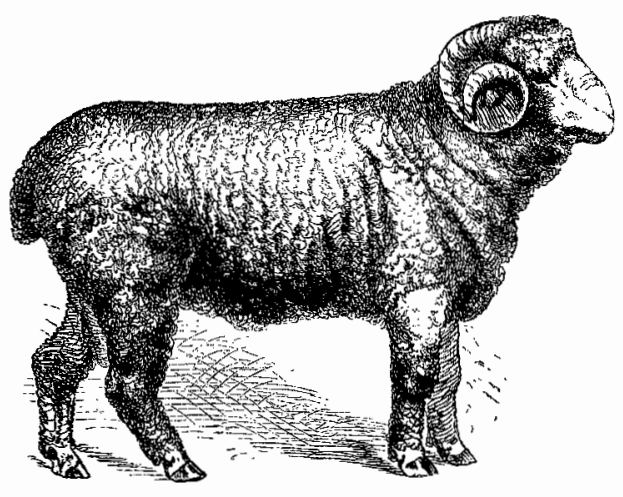




\section{On Not Making Connections: Why Environmental Ethicists Still Eat Meat}

We have seen above that what we eat is not a matter of subjective preference alone. Serious moral issues are involved in making this choice, and environmentally conscious and conscientious persons generally ought to inform themselves about these and to become vegetarians in consequence. It's as simple as that. But even self-avowed holistic environmental philosophers often fail to see the connections or else ignore, bury or rationalize them. My hypothesis is that their inability or unwillingness to make ethical connections between environmental concern and a vegetarian diet is motivated by the same factors that influence members of the general population who remain wedded to carnivorous eating habits, the principal difference being that environmental ethicists have more subtle, intellectualized ways of legitimating their choice.

To understand the dynamics of this process we must first come to terms with the meaning of meat. Anthropologist Nick Fiddes argues that meat and meat eating possess profound cultural significance and that the institutions surrounding them affirm the ideology governing our relationship to nature. Fiddes writes:

Meat is flesh of what were once living animals; it is destined for our physical consumption. This makes it an exceptionally well suited exemplification of our ability to control and vanquish the non-human worlda goal...upon which we have...placed great emphasis (Fiddes 1991: 173).

Belief in human dominion does not merely legitimate meat eating - the reverse is also true: meat reinforces that presumption. Killing, cooking, and eating other animals' flesh provides perhaps the ultimate authentication of human superiority over the rest of nature, with the spilling of their blood a vibrant motif (Fiddes 1991: 65).

In accordance with this symbolic link, meat has been invested, in our own and other cultures, with a number of interesting properties, among which are: association with strength and aggression; high social value and the capacity to confer status; being equated with "the very idea of food itself" (Twigg 1983: 21; cited in Fiddes
1991: 13); and bearing the weight of sustaining the masculinized myth of Homo Sapiens as a preeminently hunting species. Meat is the quintessential symbol of our species' domination of nature, our capacity to transform life into death, to conquer and exploit what is other, what is at our mercy. Meat is also a highly visible symbol, reminder and reinforcer of patriarchal control in all of its manifestations. Meat is masculine food, powerful food; to be a "real man" is to eat meatlots of it, and the redder the better. And to be a "real man" is to be what our society holds up as the most valid and valuable kind of human being. We may fancy that we aren't so simple-minded or biased as to be gulled by such crude associations of ideas and emotions. But in a culture like ours, it is difficult to be sure. Without engaging in a lengthy process of critical selfexamination, no one can be completely confident of immunity from influences of this sort.

Fiddes reminds us too that "Children have traditionally been brought up to regard consuming the flesh of other animals as both normal and desirable." It is therefore not surprising that "Meat eating is...a principle unquestioned by most people" (Fiddes 1991: 5). Furthermore, the ideas symbolically associated with meat eating "need seldom, if ever, be directly thought in order to be significantly influential. They can operate at a level of cultural consensus rather than individual awareness, and may be all the more powerful for that" (Fiddes 1991: 229). For such associations and meanings readily nourish the weakness of will, self-deception and rationalization that block moral decision-making.

What happens when this complex mental set is confronted and brought into question? As part of the structure of humans' power over nature, meat eating is a political act. And to take issue with this practice is therefore a subversive act. Fiddes writes:

To dispute that the individual has unlimited rights over animals is to defy an almost sacred tenet of our common ideology-it is to imply that the power of human culture over nature is limited, and that is indeed controversial in a society in which human supremacy has for so long been a central ethos (Fiddes 1991; 64).

It follows that considerable resistance can be expected to meet any such challenge, with corresponding attempts to undermine, discredit, marginalize, ridicule, silence, 
and intimidate those who have breached the assumed common ideology of nature domination. Strong economic vested interests will also predictably reinforce these responses. Such a backlash is readily observable and well documented (Adams 1991; Fiddes 1991). An instructive example is provided by the case of Canadian country music star k.d. lang, who, because of her public stand against meat eating, has recently been declared "anti-agriculture" by an official of the province of Alberta and has had to cancel concerts for fear of inciting hostile redneck mob behavior. Her avowed lesbianism has also been used, by association, to discredit her message. In short, interrogating the culturally prevalent practice of meat eating poses a threat to the accepted notion of human supremacy over nature and, consequently, stirs up potent counterforces. It can be dangerous to your health to go against the grain in this manner.

There is bound to be considerable personal resistance to changing dietary habits as well, since for each of us these have become enmeshed in a complex network of meanings surrounding cultural practices, rituals, expressions of friendship, modes of selfrecognition, even sexual self-identification (Adams 1991). Sharon Bloyd-Peshkin observes that:

diet is one of the most personal of habits. People have a long-standing and deep emotional attachment to the foods they eat. What a person ate as a child will always spell comfort, and for many people, the foods they eat express the culture they come from or the class [one could add: race and sex] they belong to.... In addition, people who change their diets find their relationships with their colleagues, family and friends affected.... Other habits don't carry this emotional weight.... Giving up the foods you were raised on is a very large sacrifice-if you can do it at all (Bloyd-Peshkin 1991: 70).

Obstacles to be overcome in changing to a vegetarian diet, then, are not only cultural-political but also cultural-personal and tied up with socialization and intimate habits that shape our self-identities. These can be a powerful deterrent to change. One might expect all of these elements to play as great a part in determining the outlook of environmental ethicists who still eat meat and even defend their doing so. However,
I shall look briefly at but one aspect of this process: their ethical rationalizations.

The anthropocentric, dominionist, patriarchal ideology that undergirds meat eating and modern livestock producing practices surfaces in a somewhat disguised but still quite apparent form in the writings of some of today's leading environmental ethicists. J. Baird Callicott, for example--probably the most ardent and prolific exponent of the land ethic-explains Leopold's dedication to hunting and lack of concern over eating meat and over the abysmal treatment of domesticated animals as the products of a "different theoretical foundation," "cosmic vision" or "substratum of thought and value" from those shared by animal liberationists (Callicott 1989: 17, 18). According to his account Leopold's land ethic is not to be viewed as inconsistent with these acts and attitudes. However this strikes me as merely designed to neutralize an embarrassing lack of ability to make connections at the heart of the theory which in other respects endeavors to forge and render them visible to us. ${ }^{4}$

Callicott, for his own part, has claimed (allegedly in the spirit of the land ethic) that universal vegetarianism would swell the earth's human population because of the greater availability (in principle) of food supplies, and "is therefore probably ecologically catastrophic" (Callicott 1989: 35). This concern would scarcely seem primary in a world of mass starvation whose population grows exponentially, the prevalence of meat eating notwithstanding. Critics of moral vegetarian arguments typically assume, to their obvious advantage, a scenario in which world food production changes completely overnight and a universal vegetarian economy springs into existence from nowhere (e.g. Frey 1983: Chap. 17). This of course is an absurdity which no thoughtful visionary would entertain seriously. Many questions remain: what a global approach to sustainable agriculture might look like; whether free-ranging livestock could support the world's present and future demand for meat and other animal food products; whether decreased consumption of these foodstuffs might be an ethically attractive option to vegetarianism; whether even a major, gradual shift to vegetarianism is likely to contribute directly to the relief of world hunger; and whether (and to what extent) the richer nations of the world are morally obligated to feed the poorer ones. But these should not deter us from conducting an ethical enquiry into the connections between what we eat and its consequences. 
Callicott argues further that "The important thing... is not to eat vegetables as opposed to animal flesh, but to resist factory farming" of both animals and plants. He draws support for this statement from the observation that "The land ethic... helps us to recognize and affirm the organic integrity of self and the untenability of a firm distinction between self and environment" (Callicott 1989: 36). Unfortunately this reasoning completely sidesteps the problem of animal suffering and death in the service of humans' dietary preferences. This, one would suppose, might trouble the conscience of a self dedicated to its own integrity and to experiencing connectedness with all forms of life.

A similarly blinkered but more transparently anthropocentric view can be found in the work of Holmes Rolston III, another prominent environmental ethicist. Rolston begins a discussion of domestic food animals by declaring that "Animal agriculture is tangential to an environmental ethic," though he allows that there is some weak connection between them (Rolston 1988: 78). Why does he say this? Because "Although food animals are taken out of nature and transformed by culture, they remain uncultured in their sentient life, cultural objects that cannot become cultural subjects." What follows from this? Rolston reasons that:

They ought to be treated... with no more suffering than might have been their lot in the wild, on average, adjusting for their modified capacities to care for themselves... [D]omestic animals ought to be spared pointless suffering but they have no claim to be spared innocent suffering (Rolston 1988: 79).

How does the "failure" on the part of animals to resemble their "cultured" captors and masters lend support to these startling and breathtakingly dogmatic non sequiturs? We return again to Rolston's text:

The killing and the eating of animals, when they occur in culture, are still events in nature; they are ecological events, no matter how superimposed by culture... Humans eat meat, and meat-eating is a natural component of ecosystems, one to which we do not object in nature nor try to eliminate from our cultural interactions with nature (Rolston 1988; 79-80).
This is an interesting observation from one who has asserted only a page earlier that "Domestic animals are breeds, no longer natural kinds" (Rolston 1988: 78). Also worthy of note is Rolston's appeal to the cherished view that when humans eat meat they are merely acting "naturally" or "instinctually," just as other predators do in the wild. What we see here, however, is but another example of a common speciesist ploy: humans, claiming themselves to be superior to other species (not least because of their capacity for ethics), justify their behavior as "following nature" when it suits them to do so and conveniently shield themselves from comparisons with other species when that is more advantageous. Not only this, but the assumption is being made, as it frequently is in such arguments, that humans are natural omnivores who have defined their culture through hunting, etc., even though there is much evidence to the contrary (Fiddes 1991).

Humans, then, Rolston maintains, have no duty not to eat sentient animals because they would do so in a state of nature. To think otherwise is to confuse human ethics with environmental ethics, or to "see ourselves in fur" (Rolston 1988: 80). Why is it an error to "see ourselves in fur" when it comes to the question of eating animals? Because animals suffer less than humans; "they do not suffer the affliction...that humans would if bred to be eaten." This argument seems merely bizarre: humans may eat animals because they are capable of greater suffering than animals. (An additionally confounding claim is made a few pages later, where Rolston asserts that food animals suffer only "instrumental pain, so designated because it serves a higher good. "Instrumental pain" is not as bad as "intrinsic pain," which is "a bad thing, absolutely" [Rolston 1988: 82]. This might be an interesting point for someone, somewhere, to ponder who is being tortured "for the good of the state!").

But there is more involved here than considerations about pain and suffering. Rolston claims that the "value destruction" involved in the killing of humans for food would be greater than in the killing of animals for food. Leaving aside the puzzling eccentricity of tying this whole discussion to the consequences of cannibalism, a reasonable reply is that if we are seriously going to worry about value destruction, it seems plain that less of it will be caused by eating plants and plant products than by eating animals, and so we ought accordingly to choose this less destructive course of action. 


\section{Conclusion}

It has been shown that meat eating not only causes much suffering and death to sentient nonhuman animals, but also is inseparable from activities that are ecologically damaging and environmentally unsustainable. These activities, in addition, are antithetical to the aims of social justice and equality, which are part of the wider meaning of sustainability. For meat eating is bound up with the oppression and exploitation of others elsewhere in the world who have less than we do of the basic necessities of life-in large measure because we have more than we need. Meat eating therefore contributes materially to the process whereby the poorer citizens of the world have their interest in a better life denied, while at the same time it promotes the identical interest of the more affluent.

I have argued that many environmental ethicistseven those claiming to be ethical holists - do not make connections that ought to be made between large-scale ethical issues which should concern us all. These issues make vegetarianism a moral imperative. Animal liberation theories stress sentience in their critique of the meat industry and judge that the suffering it causes to nonhuman animals makes meat eating immoral. Animal rights theories place emphasis on the possession of interests and rights by nonhuman animals and find herein the moral basis for opposing meat eating. One might expect that an ethical outlook which purports to be more overarching than these would bring the sorts of connections discussed earlier into even sharper focus. However environmental ethicists who omit or refuse to change their dietary habits reveal a commitment to holism that is more abstract, notional and inconsistent than it is substantive and of practical significance.

According to one analysis, many environmentalists do not choose to become vegetarians because they identify vegetarianism with animal rights advocacy, and this in turn with principles and policies that stand in opposition to projects that concern them most, such as wildlife management, environmental research, feral population control, and culling of "overpopulated" species (Bloyd-Peshkin 1991). It may be that environmental ethicists share these concerns, and that this is part of their motivation as well. There are undoubtedly major difficulties to be encountered in addressing these sorts of environmental issues from the standpoint of animal rights or animal liberation theories, and it has not been demonstrated yet whether or how these problems can be worked out. However, it would be unfortunate and, as I hope I have shown, also mistaken to infer from the limitations of animal rights/animal liberation theories and the absence of an adequate rapprochement between these and environmental holism that vegetarianism is not ethically obligatory. Nor is there any justification in today's world for the attitude of leading environmental activists who reportedly trivialize dietary choice by labeling it a "personal and lifestyle issue" (Bloyd-Peshkin 1991: 68).

As long as environmental ethicists continue to ignore the issue of vegetarianism, it will be difficult to take seriously their claims to be the proponents of a new holistic ethic. Indeed, when we examine vegetarianism as a test case, it appears that those in the animal rights/ animal liberation movement exhibit, by means of their personal choices and organizational policies, a deeper commitment to a holistic outlook on nature. One animal activist makes this clear by succinctly stating:

Animals are part of the environment, they are endangered species, they are being used in exploitative ways that are bad for the environment. And certainly, along with us, they will be victims in any nuclear holocaust. All those things make the connections between the overall environmental and antinuclear movements pretty obvious. The ones that are not so obvious, but where I think we must make the liaison, is with the consciousness about racism and the woman's movement and the gay movement (Sally Gearhart, cited in Sperling 1988: 101).

A closer dialogue with these individuals might therefore serve environmental ethicists well. It might, by the same token, win their voices greater credibility.

But more requires to be done as well. Environmental ethics must move in the direction indicated by ecofeminist theory in some of its more recent manifestations. Lori Gruen (Gruen 1993: 80, 84) explains that:

Ecofeminists must...attempt to establish a different system of values in which the normative category of "other" (animals, people of color, "Third World" people, the lower classes, etc.) is reevaluated. By recognizing that the exploitation that occurs as a result of establishing power over one 
group is unlikely to be confined to that group only, ecofeminists are committed to a reexamination and rejection of all forms of domination.... Making connections, between the various ways in which oppression operates and between those individuals who suffer such oppression, will allow all beings to live healthier, more fulfilling, and freer lives.

What this form of analysis helps us see is that consistency in theorizing, and between theory and practice, is not just a purely "rational" value that philosophers cherish and that everyone should aim to realize; it is also a matter of seeing connections between what we believe, espouse and do, and that this in turn can lead us to a better understanding of what it means to minimize the harm that we cause by our choices and to live more lightly on the planet. ${ }^{5}$

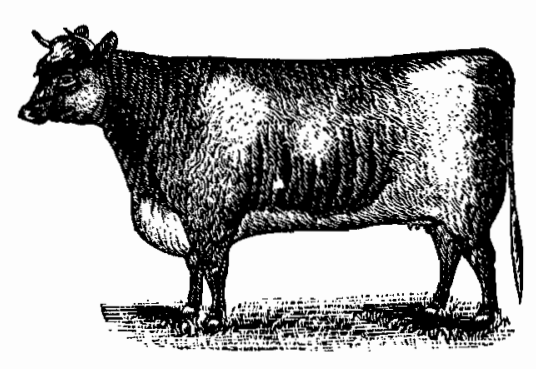

\section{Notes}

${ }^{1}$ Blackstone (1974); Roelofs et al. (1974); Goodpaster \& Sayre (1979); Science Coalition \& Fritsch (1980); Mannison et al. (1980); Partridge (1981); Shrader-Frechette (1981); Elliot \& Gare (1983); Scherer \& Attig (1983); Regan (1984); VanDeVeer \& Pierce (1986); Billmoria (1992); Hargrove (1992); Hart (1992); Armstrong \& Botzler (1993); List (1993); Zimmerman et. al. (1993). The one is Regan (1984).

${ }^{2}$ See, for example, Hypatia (1991); Gaard (1993).

${ }^{3}$ One might make sense of the notion of a duty to oneself here in the following way. It may be a deontic (or obligatory) virtue that one engage in a process of self-realization or a quest for personal excellence, in which maintaining one's physical health would likely figure as a central feature. Or it could be argued that one ought to strive to understand and seek to attain the optimum state of species well-being that is appropriate to being fully human.

\begin{abstract}
${ }^{4}$ This point would remain no less forceful even if (a big if) we were to concede the often-voiced arguments that (a) hunters are exemplary nature lovers and conservationists, and (b) it's better to kill your own meat than to have someone else do the dirty work for you. For whatever the merits of these arguments, they somehow distract our attention from the principal issue, which is whether one's individual choices and decisions support a grossly inhumane and wasteful mechanized system of generating animal products for human consumption.

${ }^{5}$ Earlier versions of this paper were presented at the "Ethics, Animals and Society" conference held at the University of Guelph, Guelph, Ontario, Canada, 20-22 March 1992, and at the Queen's University Philosophy Colloquium, 18 February 1993. I would like to acknowledge, with appreciation, comments on these earlier drafts by Eugene Hargrove, Sue Hendler, Bill Holder, Wayne Ouderkirk, Christine Overall and Richard A. Watson.
\end{abstract}

\section{References}

Adams, Carol J. (1991). The Sexual Politics of Meat: A Feminist-Vegetarian Critical Theory. New York: Continuum.

Akers, Keith (1983). A Vegetarian Sourcebook. Arlington, VA: Vegetarian Press.

Armstrong, Susan J. and Botzler, Richard G., eds. (1993). Environmental Ethics: Convergence and Divergence. New York: McGraw-Hill.

Barnard, Neal D. (1990). The Power of Your Plate: A Plan for Better Living. Summertown, TN: Book Publishing.

Billmoria, Purusottama (1992). Environmental Ethics. Geelong, Victoria, Australia: Deakin University.

Blackstone, William T., ed. (1974). Philosophy and Environmental Crisis. Athens: University of Georgia Press.

Bloyd-Peshkin, Sharon (1991). "Mumbling About Meat." Vegetarian Times, No. 170 (October), 66 ff.

Callicott, J. Baird (1989). In Defense of the Land Ethic: Essays in Environmental Philosophy. Albany: State University of New York Press.

Durning, Alan (1991). "Fat of the Land: Livestock's Resource Gluttony.” World Watch, 4/3 (May-June), 11-17.

Elliot, Robert and Gare, Arran, eds. (1983). Environmental Philosophy. University Park: Pennsylvania State University Press.

Fiddes, Nick (1991). Meat: A Natural Symbol. New York: Routledge, Chapman \& Hall. 
Frankena, W.K. (1979). "Ethics and the Environment." In Goodpaster, K.E. and Sayre, K.M., eds. Ethics and Problems of the 21st Century. Notre Dame: University of Notre Dame Press. Pp. 3-20.

Frey, R.G. (1983). Rights, Killing and Suffering: Moral Vegetarianism and Applied Ethics. Oxford: Blackwell.

Gaard, Greta, ed. (1993). Ecofeminism: Women Animals. Nature. Philadelphia: Temple University Press.

Gold, Mark (1991). "On the Meat-Hook." New Internationalist, No. 215 (January), 9-10.

Hargrove, Eugene, ed. (1992). The Animal Rights/Environmental Ethics Debate: The Environmental Perspective. Albany: State University of New York Press.

Hart, Richard E., ed. (1992). Ethics and the Environment, Lanham, MD: University of America.

Hypatia (1991). Special Issue: "Ecological Feminism." Ed. Karen J. Warren. Vol. 6, No. 1 (Spring).

Johnson, Lawrence E. (1991). A Morally Deep World: An Essay on Moral Significance and Environmental Ethics. Cambridge: Cambridge University Press.

Lal, R. et al. (1988). "Are Intensive Agricultural Practices Environmentally and Ethically Sound?" Journal of Agricultural Ethics, 1, 193-210.

Lappé, Frances Moore (1975). Diet for a Small Planet. Rev. ed. New York: Ballantine.

Leopold, Aldo (1970). A Sand County Almanac with Essays on Conservation from Round River. New York: Sierra Club/ Ballantine.

List, Peter C. (1993), Radical Environmentalism: Philosophy and Tactics. Belmont, CA: Wadsworth.

Mannison, Don et al., eds. (1980). Environmental Philosophy. Monograph Series, No. 2. Canberra: Department of Philosophy, Research School of Social Sciences, Australian National University.

Mason, Jim and Singer, Peter (1980). Animal Factories. New York: Crown.

Patridge, Ernest, ed. (1981). Responsibilities to Future Generations. Buffalo: Prometheus Books.

Pimentel, David (1990). "Environmental and Social Implications of Waste in U.S. Agriculture and Food Sectors." Journal of Agricultural Ethics, 3, 5-20.

Redclift, Michael (1987). Sustainable Development: Exploring the Contradictions. London: Routledge.
Regan, Tom (1982). All That Dwell Therein: Essays on Animal Rights and Environmental Ethics. Berkeley and Los Angeles: University of California Press.

(1983) The Case for Animal Rights. Berkeley and Los Angeles: University of California Press.

ed. (1984). Earthbound: New Introductory Essays in Environmental Ethics. New York: Random House.

Robbins, John (1987). Diet for a New America. Walpole, NH: Stillpoint Publishing.

Roelofs, Robert T. et al. (1974). Environment and Society: A Book of Readings on Environmental Policy, Attitudes and Values. Englewood Cliffs, NJ: Prentice-Hall.

Ralston, Holmes III (1983). Environmental Ethics: Duties to and Values in the Natural World. Philadelphia: Temple University Press.

(1986). Philosophy Gone Wild: Essays in Environmental Ethics. Buffalo: Prometheus Books.

Scherer, Donald and Attig, Thomas, eds. (1983). Ethics and the Environment. Englewood Cliffs, NJ: Prentice-Hall.

Science Action Coalition with Fritsch, Albert J. (1980). Environmental Ethics: Choices for Concerned Citizens. Garden City, NY: Anchor Press/Doubleday.

Shrader-Frechette, K.S. (1981). Environmental Ethics. Pacific Grove, CA: Boxwood Press.

Stone, Christopher D. (1987). Earth and Other Ethics: The Case for Moral Pluralism. New York: Harper \& Row.

Singer, Peter (1990). Animal Liberation. New rev, ed. New York: Avon Books.

Sperling, Susan (1988). Animal Liberators: Research and Morality. Berkeley and Los Angeles: University of California Press.

Taylor, Paul W. (1986). Respect for Nature: A Theory Of Environmental Ethics. Princeton: Princeton University Press

Twigg, J. (1983). "Vegetarianism and the Meanings of Meat." In A. Murcott, ed. The Sociology of Food and Eating: Essays on the Sociological Significance of Food. Aldershot, UK: Gower.

VanDeVeer, Donald and Pierce, Christine, eds. (1986). People, Penguins and Plastic Trees: Basic Issues in Environmental Ethics. Belmont, CA: Wadsworth.

Zimmerman, Michael E. et al., eds. (1993). Environmental Philosophy: From Animal Rights to Radical Ecology. Englewuod Cliffs, NJ: Prentice-Hall. 